\title{
New peptide-based and animal-free coatings for animal cell culture in bioreactors
}

\author{
Youlia Serikova ${ }^{1 *}$, Aurélie Joly ${ }^{1}$, Géraldine Nollevaux ${ }^{1}$, Martin Bousmanne ${ }^{2}$, Wafa Moussa ${ }^{2}$, Jonathan Goffinet ${ }^{3}$, \\ Jean-Christophe Drugmand ${ }^{3}$, Laurent Jeannin ${ }^{2}$, Yves-Jacques Schneider ${ }^{1}$ \\ From 23rd European Society for Animal Cell Technology (ESACT) Meeting: Better Cells for Better Health \\ Lille, France. 23-26 June 2013
}

\section{Background}

Anchorage dependent cells require an appropriate extracellular matrix for their survival, migration, proliferation, phenotyping and/or differentiation [1-3]. These cells interact with extracellular matrix proteins, primarily through integrins, which induces focal adhesion contacts assembly and activation of signalling pathways that regulate diverse cellular processes [4].

Culture supports usually include biochemical components allowing such cells to adhere and to reconstitute an extracellular environment close to that found in vivo. Currently, this artificial environment is achieved by extracellular matrix constituents deposition, adsorption or grafting; among them collagens, fibronectin, laminin, artificial lamina propria... [5]. However, such animal proteins used in cell culture may induce pro-inflammatory stress, be unstable against proteolysis or loose activity after adsorption [6,7]. Synthetic microenvironments should be more suitable for clinical purposes: (i) improved control of physicochemical and mechanical properties, (ii) limited risks of immunogenicity, (iii) increased biosafety (animal free) and (iv) facilitated scale-up [1].

In this framework, research has recently focused on synthetic peptides or peptidomimetics that can mimic the extracellular matrix. Such molecules can be immobilized as recognition motifs on the surface of culture supports with a greater stability and easier surfaces characterization [5]. Self-assembling peptide hydrogels could mimic the chemical and mechanical aspects of the natural extracellular matrix $[8,9]$ by undergoing large deformations, as in mammalian tissues. They have an inherent biocompatibility and should be able to direct cell behaviour [10]. They

\footnotetext{
*Correspondence: youlia.serikova@uclouvain.be

'Laboratory of Cellular, Nutritional and Toxicological Biochemistry, Institute of Life Sciences, UCLouvain, 1348 Louvain-la-Neuve, Belgium

Full list of author information is available at the end of the article
}

also can be functionalized with various biologically active ligands constituting good candidates to a new range of smart biomaterials, able to ensure adhesion of different cell types [11-13].

The range of biomimetic peptides that direct cell adhesion and are recognized by integrins is large. Recognition sequences derived from different extracellular matrix proteins include RGD [1], which are specific to different cell lines $[1,5,6]$.

In this context, this work aims at designing animal-free, chemically defined and industrially scalable coatings for animal cell culture, as an alternative to collagen, fibronectin or Matrigel ${ }^{\circledR}$ for laboratory and industrial large scale applications. These are based on self-assembling short peptides bearing adhesion bioactive sequences like RGDderived or other adhesion sequences developed to coat polystyrene or polyethylene terephthalate surfaces. Adhesion sequences should be recognized by cells, which should favour their anchorage and spreading.

\section{Experimental}

Bioactive self-assembling peptide sequences were synthesized in liquid phase, purified, analytically characterised and manufactured by Peptisyntha (Brussels, Be) in GMP conditions, as sterile coating solutions. They were used to coat polystyrene flasks (Corning Inc., NY) in comparison with animal-derived coatings i.e. collagen and fibronectin.

Human Adipose Derived Stem Cells (hADSC) were purchased from Lonza (Verviers, Be); Caco-2, MRC-5 and $\mathrm{CHO}$ cells, obtained from ATCC. Cells were seeded at 8000 cells $/ \mathrm{cm}^{2}$ and cultured until 7 days. After $60 \mathrm{~h}$ or 7 days of culture, cells were harvested and counted on Bürker cell in Trypan blue or fixed. Nuclei were then stained with DAPI and actin filaments with RhodaminPhalloidin. Fluorescence microscopy was used to observe 
cell morphology and NIS software allowed cell-spreading determination.

\section{Results and discussion}

The absence of cytotoxicity was assayed with necrosis (LDH) and cell metabolic activity (MTT) tests on different cell lines (Caco-2, MRC-5, CHO, hADSC). No cytotoxicity was detected.

Two variants of bioactive self-assembling peptides, both containing RGD-derived sequences, were compared with animal-derived coatings (collagen and fibronectin) in serum-poor of free medium. Cytocompatibility and dose dependent response studies revealed that peptides promote cell adhesion and growth.

As for hADSC culture, these cells were first incubated in a serum-free medium during 6 to $24 \mathrm{~h}$ and the proportion of adherent cells and their spreading was evaluated. hADSC cells needed more than $6 \mathrm{~h}$ to fully adhere to the culture surface and the adhesion effectiveness appeared better for collagen and the first variant of peptide than for the other substrate coatings. Initial spreading was more marked on fibronectin, but then increased from 6 to 24 hours on all coatings.

A second experiment consisted in a first cell incubation in DMEM supplemented with 1\% Fetal Bovine Serum (FBS) and, after $24 \mathrm{~h}$, the medium was replaced by DMEM supplemented with 10\% FBS. After 7 days, the best cell growth was observed for substrates coated with collagen and peptide 1 , fibronectin and peptide 2 being slightly less efficient. In parallel, cell spreading decreased or remained constant upon cell proliferation (Figure 1).

As for Caco-2 cells culture, these cells were incubated in a serum-free, hormono-defined medium (BDM) during 6 to $24 \mathrm{~h}$ and the proportion of adherent cells and

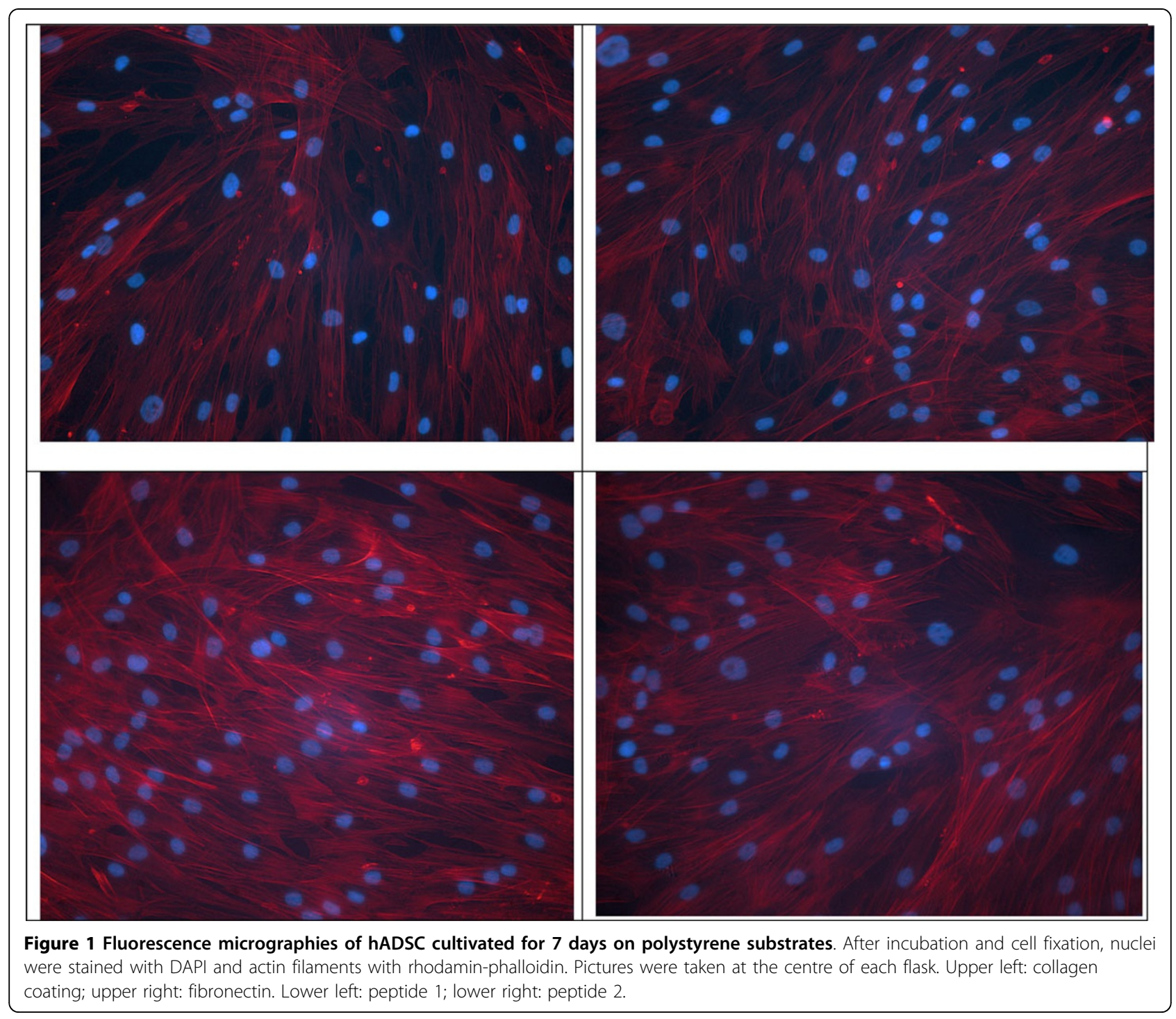


their spreading were evaluated. These cells required a shorter duration than hADSC to adhere on the surface and the adhesion effectiveness appeared a little bit better for collagen and fibronectin. Initial spreading was more marked on collagen and its importance varies between 6 and $24 \mathrm{~h}$ on different coatings.

The second experiment consisted in a first cell incubation in a serum-free medium and, after $24 \mathrm{~h}$, the nutritive medium was replaced by a medium supplemented with $1 \%$ FBS. After $60 \mathrm{~h}$, there was almost no difference between the different coatings. Nevertheless, after 7 days, cells cultured on peptides reached the same effectiveness as on fibronectin, but slightly lower than collagen. As for hADSC, cell spreading decreased upon cells proliferation.

\section{Conclusion}

Designed self-assembling bioactive peptides are not cytotoxic and are cytocompatible. Cell adhesion and growth on peptide coatings appear as effective as on animalderived coatings and the peptide coatings allow easy cell harvesting after culture.

Globally, the results indicate that self-assembling bioactive peptides constitute chemically defined, entirely synthetic and effective promoters of cell adhesion, spreading and proliferation.

\section{Acknowledgements}

This work is supported by Innoviris (Brussels Region) in the scope of a Doctiris PhD grant.

\section{Authors' details}

'Laboratory of Cellular, Nutritional and Toxicological Biochemistry, Institute of Life Sciences, UCLouvain, 1348 Louvain-la-Neuve, Belgium. ${ }^{2}$ Peptisyntha sa,

1120 Brussels, Belgium. ${ }^{3}$ ATMI, 1120 Brussels, Belgium.

Published: 4 December 2013

\section{References}

1. Petrie TA, Garcia AJ: Extracellular Matrix-derived Ligand for Selective Integrin Binding to Control Cell Function. Biol Interact Mater Surf 2009, 1:133-156.

2. Hynes RO: The Extracellular Matrix: Not Just Pretty Fibrils. Sci 2009, 326:1216-1219.

3. Rahmany MB, Van Dyke M: Biomimetic approaches to modulate cellular adhesion in biomaterials: A review. Acta Biomater 2013, 9:5431-5437.

4. Badami AS, Kreke MR, Thompson MS, Riffle JS, Goldstein AS: Effect of fiber diameter on spreading, proliferation, and differentiation of osteoblastic cells on electrospun poly(lactic acid) substrates. Biomater 2006, 27:596-606.

5. Shin $H$, Jo S, Mikos AG: Biomimetic materials for tissue engineering. Biomater 2003, 24:4353-4364.

6. Hersel U, Dahmen C, Kessler H: RGD modified polymers: biomaterials for stimulated cell adhesion and beyond. Biomater 2003, 24:4385-4415.

7. Lin CC, Metters AT: Hydrogels in controlled release formulations: Network design and mathematical modeling. Adv Drug Deliv Rev 2006, 58:1379-1408.

8. Wu EC, Zhang S, Hauser CAE: Self-Assembling Peptides as Cell-Interactive Scaffolds. Adv Funct Mater 2012, 22:456-468.

9. Hamilton SK, Lu H, Temenoff JS: Micropatterned Hydrogels for Stem Cell Culture. Stud Mechanobiol Tissue Eng Biomater 2010, 2:119-152.

10. Jayawarna V, Ali M, Jowitt TA, Miller AF, Saiani A, Gough JE, Ulijn RV: Nanostructured Hydrogels for Three-Dimensional Cell Culture Through
Self-Assembly of Fluorenylmethoxycarbonyl-Dipeptides. Adv Mater 2006, 8:611-614.

11. Bhat NV, Upadhyay DJ: Plasma-induced surface modification and adhesion enhancement of polypropylene surface. J Appl Polym Sci 2002, 86:925-936.

12. Varghese $\mathrm{S}$, Elisseeff $\mathrm{JH}$ : Hydrogels for Musculoskeletal Tissue Engineering. Adv Polym Sci 2006, 203:95-144.

13. Tessmar JK, Göpferich AM: Customized PEG-Derived Copolymers for Tissue-Engineering Applications. Macromol Biosci 2007, 7:23-39.

doi:10.1186/1753-6561-7-S6-P15

Cite this article as: Serikova et al:: New peptide-based and animal-free coatings for animal cell culture in bioreactors. BMC Proceedings 2013 7(Suppl 6):P15

\section{Submit your next manuscript to BioMed Central and take full advantage of:}

- Convenient online submission

- Thorough peer review

- No space constraints or color figure charges

- Immediate publication on acceptance

- Inclusion in PubMed, CAS, Scopus and Google Scholar

- Research which is freely available for redistribution

Submit your manuscript at www.biomedcentral.com/submit 